\title{
ANALISIS PERANGKAT PEMBELAJARAN KURIKULUM 2013 DI SEKOLAH DASAR
}

\author{
Alexander Hamonangan Simamora \\ Jurusan Teknologi Pendidikan, Universitas Pendidikan Ganesha \\ e-mail : alexandersimamora88@gmail.com \\ I Komang Sudarma \\ Jurusan Teknologi Pendidikan, Universitas Pendidikan Ganesha \\ e-mail :sudarmadede@gmail.com
}

\begin{abstract}
Abstrak
Penelitian yang dilakukan memiliki tujuan untuk menganalisis perangkat pembelajaran pada kurikulum 2013 berupa: (1) rencana pelaksanaan pembelajaran (RPP), (2) buku guru dan buku siswa, dan (3) lembar kerja siswa (LKS) yang diterapkan di sekolah dasar (SD) ditinjau dari aspek persiapan, proses, dan hasil. Tujuan khusus yang ingin dicapai melalui penelitian ini adalah untuk: (1) mendeskripsikan hasil analisis RPP ditinjau dari Permendikbud RI Nomor 22 tahun 2016 tentang Standar Proses pada Pendidikan Dasar dan Pendidikan Menengah dan teori desain pembelajaran, (2) mendeskripsikan hasil analisis LKS ditinjau dari pengembangan nilai-nilai karakter sebagaimana tuntutan dalam kurikulum 2013, dan (3) mendeskripsikan hasil analisis buku guru dan buku siswa ditinjau dari aspek desain pesan pembelajaran. Penelitian ini termasuk penelitian evaluasi. Instrumen yang digunakan adalah kuesioner, pencatatan dokumen, dan wawancara. Perangkat pembelajaran dikumpulkan dengan teknik kluster sampling, yaitu mengelompokkan berdasarkan sekolah. Setiap sekolah ditentukan 6 guru dan diambil masing-masing enam silabus, enam, RPP, enam LKS, dan enam buku teks pelajaran. Dengan demikian jumlah sampel keseluruhan adalah: 18 guru, 18 RPP, 18 LKS, dan 6 buku teks pelajaran. Teknik analisis data yang digunakan adalah teknik analisis deskriptif kualitatif dan analisis statistik deskriptif. Hasil penelitian menunjukkan bahwa: persiapan dan proses yang dilakukan guru dalam membuat perangkat pembelajaran sudah sangat baik. Berdasarkan hasil analisis, RPP yang dihasilkan oleh para guru berada pada kategori baik, LKS berada pada kategori sangat kurang, dan buku teks berada pada kategori sangat baik.
\end{abstract}

Kata kunci: Kurikulum, Silabus, RPP, Buku teks, LKS

\begin{abstract}
The research has purpose to analyze the set of learning on curriculum 2013 such as: (1) lesson plan, (2) teacher books and student books, and (3) student work sheet. It has a particular purposes followings are: (1) describing the result of lesson plan analysis based on the rule of educational and cultural ministry of Indonesia number 22 in 2016 which indicate the standard in processing for elementary school and high school and theory of learning design, (2) describing the result of student work sheet analysis in developing character value based on curriculum 2013, and (3) Analyzing the result of teacher books and student books analysis. The research is indicated evaluation research. The instruments were used such as Questionnaire, document recording, and interview. The set of learning was submitted by using cluster sampling technique, These are: classify based on the school. Each school consists of 6 teachers, 6 syllabus, 6 lesson plans , 6 students work sheet, and 6 text books. Based on the data that the number of sample: 18 teachers, 18 lesson plan, 18 students work sheet, and 6 text books. It used qualitative descriptive analysis and descriptive statistic analysis. The result of research showed that the preparation and process had been good in making the set of learning by the teachers. Based on the result of analysis, the result of teachers' lesson plan is good category, while the position of students work sheet is very not quite, and the result of text book analysis is very good category.
\end{abstract}

Keywords: Curriculum, Syllabus Lesson plan, text book, student work sheet

\section{Pendahuluan}

Kurikulum 2013 merupakan kurikulum yang diharapkan dapat membentuk insan yang berkarakter. Tujuan ini nampak jelas pada perumusan kompetensi pada kurikulum 2013 yang menempatkan sikap spiritual di urutan yang pertama. Pada kurikulum 2013 ada empat pengembangan kompetensi yang dikenal dengan istilah kompetensi inti (KI), yaitu KI-1 berhubungan dengan sikap spiritual, KI-2 yang berhubungan dengan sikap sosial, KI-3 yang berhubungan dengan aspek pengetahuan, dan KI-4 yang berhubungan dengan aspek keterampilan.

Akhir-akhir ini penerapan kurikulum 2013 mengalami perubahan, yaitu bagi sekolah yang siap dari segi sumber daya manusia dan sarana dan prasarana dapat menerapkan kurikulum 2013 sedangkan bagi sekolah yang belum siap dapat kembali menerapkan kurikulum KTSP. Khususnya di Bali, beberapa sekolah telah menerapkan kurikulum 2013. Misalnya saja di Kabupaten Buleleng ada enam sekolah yang menerapkan 
kurikulum 2013 di tingkat sekolah dasar, yaitu SD 3 Banjar Jawa, SD 4 Kaliuntu, SD 4 Kampung Baru, SD 6 Pejarakan, SD 9 Busungbiu, dan SD Lab Undiksha (Bali.Trbunnews, 2014).

Penerapan kurikulum 2013 ternyata tidak selamanya berjalan lancar. Berdasarkan hasil studi pendahuluan menunjukkan bahwa beberapa guru SD di Kabupaten Buleleng yang telah menerapkan kurikulum 2013 mengalami kendala atau beberapa kesulitan. Kesulitan yang dialami adalah dalam membuat instrumen penilaian sikap yang termuat dalam perencanaan pelaksanaan pembelajaran (RPP). Selain membuat instrumen, guru juga mengalami kesulitan ketika melakukan penilaian sikap mengingat jumlah indikator penilaian dan siswa yang cukup banyak. Hasil penelitian Winaya, et al (2015) juga menunjukkan bahwa guru sekolah dasar di Kabupaten Buleleng khususnya yang telah menerapkan kurikulum 2013 mengalami hambatan dalam merancang langkah-langkah pembelajaran. Adanya beberapa kendala yang dihadapi guru tentu akan mempengaruhi kualitas RPP yang dibuat. Dengan demikian perlu dilakukan analisis RPP pada sekolah-sekolah yang telah menerapkan kurikulum 2013.

Tidak hanya RPP, perangkat pembelajaran berupa buku teks pelajaran perlu dianalisis lebih lanjut terutama dari kajian teori desain pesan pembelajaran. Teori ini akan memberikan dampak nyata bagi perbaikan buku teks pelajaran pada kurikulum 2013 kedepannya. Kajian ini perlu dilakukan mengingat beberapa hal yang perlu diperbaiki seperti petunjuk pengerjaan latihan belum jelas, adanya ketidaksesuaian antara petunjuk dan gambar. Kesalahan-kesalahan kecil ini turut mempengaruhi persepsi siswa dalam memahami materi maupun saat mengerjakan latihan-latihan. Untuk itu, beberapa acuan yang menjadi kajian analisis buku teks pelajaran adalah (1) kemampuan buku teks pelajaran dalam menciptakan kesan positif dengan menyajikan teks dan ilustrasi yang menarik pada halaman sampul, (2) penggunaan contoh-contoh dan latihan yang berhubungan dengan kebutuhan siswa pada saat ini maupun yang akan datang, (3) pemilihan jenis, spasi, ukuran, dan tata letak huruf yang tepat, (4) penyajian gambar untuk mengkonkretkan pesan sehingga mudah diingat dan (5) petunjuk-petunjuk dalam menginter-pretasikan gambar maupun mengerjakan latihan-latihan.

Lembar kerja siswa (LKS) juga merupakan salah satu jenis perangkat pembelajaran. LKS pada kurikulum 2013 dibuat dengan memperhatikan pengembangan aspek sikap spiritual dan sikap sosial di samping itu pula aspek pengetahuan dan keterampilan. LKS yang berorientasi pada pengembangan sikap spiritual dan sosial merupakan hal baru bagi sebagian guru sehingga tidak menutup kemungkinan beberapa LKS yang dibuat belum diarahkan ke pengembangan aspek sikap tersebut. Tidak hanya belum diarahkan pada pengembangan aspek sikap, kerap masih ada beberapa LKS yang memuat kumpulan soal-soal. Prastowo (2011) mengatakan bahwa ada lima jenis LKS, yaitu (1) LKS yang membantu siswa menemukan konsep, (2) LKS yang membantu siswa menerapkan dan mengintegrasikan berbagai konsep yang telah ditemukan, (3) LKS sebagai penuntun belajar, (4) LKS sebagai penguatan, dan (5) LKS sebagai petunjuk praktikkum. Kelima jenis LKS ini dapat menjadi acuan menganalisis tipe LKS yang dibuat oleh guru dan kecenderungan jenis LKS yang diterapkan di SD.

Mengingat beberapa kendala yang dihadapi guru dalam membuat perangkat pembelajaran (RPP), beberapa kekurangan buku teks kurikulum 2013, dan belum optimalnya pengembangan LKS maka dianggap penting dilakukan penelitian evaluasi mengenai perangkat pembelajaran di sekolah dasar yang telah menerapkan kurikulum 2013.

Adapun tujuan yang ingin dicapai dalam penelitian ini yaitu: (1) mendeskripsikan persiapan penyusunan perangkat pembelajaran kurikulum 2013 di SD, (2) mendeskripsikan proses penyusunan perangkat pembelajaran kurikulum 2013 di SD, (3) mendeskripsikan hasil penyusunan perangkat pembelajaran kurikulum 2013 di SD.

\section{Metode}

Metode yang digunakan dalam penelitian ini termasuk penelitian evaluasi program yang bersifat kualitatif. Pada penelitian ini menggunakan evaluasi program model Stake yang terdiri atas: (1) persiapan, (2) proses, dan (3) hasil. Penekanan paling besar pada model ini adalah bahwa evaluator membuat keputusan tentang program yang sedang dievaluasi. Dalam model ini, data tentang persiapan, proses, dan hasil dibandingkan untuk menentukan kesenjangan antara hasil yang diharapkan dan membandingkannya dengan standar mutlak agar diketahui dengan jelas manfaat dari program yang dievaluasi.

Populasi penelitian ini adalah guru dan perangkat pembelajaran yang ada di sekolah dasar di Kabupaten Buleleng yang telah menerapkan kurikulum 2013 yang berjumlah enam sekolah dasar. Namun dalam penelitian ini diambil tiga SD sebagai populasi yaitu SD 4 Kaliuntu, SD 4 Banyuasri, dan SD Lab Undiksha. Untuk itu sampel yang digunakan bersifat kluster sampling, yaitu mengelompokkan berdasarkan sekolah. Setiap sekolah masing-masing ditunjuk enam guru, diambil enam silabus, enam RPP, enam LKS, dan enam buku teks pelajaran. Dengan demikian jumlah sampel keseluruhan adalah 18 orang guru, 18 RPP, $18 \mathrm{LKS}$, dan 6 buku teks pelajaran karena buku teks sama untuk semua sekolah yang menerapkan K13. 
Data dalam penelitian ini dikumpulkan menggunakan instrumen berupa kuesioner, pencatatan dokumen, dan wawancara. Kuesioner digunakan untuk memperoleh data tentang pandangan guru ketika mempersiapkan dan membuat perangkat pembelajaran. Pencatatan dokumen digunakan untuk mendata dan menganalisis kualitas Silabus, RPP, LKS yang dibuat guru, dan buku teks pelajaran yang diterbitkan Kemdikbud. Wawancara digunakan untuk mengantisipasi kemungkinan diperolehnya data yang kurang valid atau informasi penting terkait dengan pembuatan perangkat pembelajaran, maka pengumpulan data dilengkapi dengan teknik wawancara.

Data utama dalam penelitian ini bersifat primer yang langsung diperoleh dari sumbernya terkait persiapan, proses, dan hasil. Data yang terkumpul dalam penelitian ini berupa data kuantitatif dan data kualitatif. Oleh karena itu, pengolahan datanya menggunakan analisis deskriptif kualitatif dan analisis statistik deskriptif.

Analisis deskriptif kualitatif digunakan untuk menganalisis data yang diperoleh melalui metode wawancara dan tanggapan peneliti terkait kualitas perangkat pembelajaran yang ada di sekolah dasar ditinjau dari aspek persiapan, proses, dan hasil. Data dibandingkan pada tiga tahapan Stake yaitu: persiapan, proses, dan hasil pada matriks deskripsi dengan standar yang ada pada matriks pertimbangan kemudian disimpulkan. Dalam analisis ini ditempuh alur analisis yang terdiri dari pengumpulan data, reduksi data dan kesimpulan verifikasi.

Analisis statistik deskriptif digunakan untuk mengolah data yang diperoleh melalui kuesioner dan pencatatan dokumen terkait komponen-komponen penilaian Silabus, RPP, penilaian LKS, dan penilaian buku teks pelajaran. Data-data tersebut dianalisis menggunakan rumus persentase sebagai berikut.

$$
\text { Nilai Perolehan } \frac{\text { Skor Mentah }}{\text { Skor Maksimum }} \times 100
$$

Nilai perhitungan persentase $(\%)$ kemudian dikonversikan dalam bentuk kualitatif untuk menentukan aktualitas ketercapaian dengan menggunakan penilaian acuan patokan.

\section{Hasil dan Pembahasan}

Hasil penelitian disajikan untuk setiap tahapan sesuai dengan model Stake. Adapun tahan tersebut yaitu, tahap persiapan, proses, dan hasil.

Perangkat pembelajaran K13 yang dihasilkan guru tidak terlepas dari persiapan yang dilakukan. Data tentang persiapan guru membuat perangkat pembelajaran K13 diperoleh dengan metode wawancara.

Pada tahap persiapan menunjukkan bahwa guru-guru telah mengikuti berbagai workshop yang memberikan pemahaman lebih dalam tentang pembuatan perangkat pembelajaran kurikulum 2013. Guru juga melakukan diskusi melalui kegiatan kelompok kerja guru (KKG) sehingga penyamaan persepsi lebih cepat dan intens bisa dilakukan di tingkat guru. Adanya pengetahuan dan pemahaman yang sama dalam membuat perangkat pembelajaran kurikulum 2013 dapat menjadi persiapan awal guru untuk menghasilkan perangkat pembelajaran yang baik dan sesuai dengan peraturan yang berlaku.

Proses pembuatan perangkat pembelajaran merupakan kelanjutan dari tahap persiapan. Untuk mengetahui proses yang dilakukan guru membuat perangkat pembelajaran 2013 dilakukan melalui metode wawancara.

Berdasarkan hasil wawancara, bahwa langkah pertama yang dilakukan guru membuat perangkat pembelajaran khususnya RPP adalah melakukan analisis terhadap KD dan mengembangkan KD menjadi beberapa indikator. Istilah lain dari proses ini adalah melakukan analisis instruksional yaitu merumuskan kompetensi umum menjadi kompetensi yang lebih spesifik. Langkah kedua, yaitu guru mengembangkan materi dengan acuan buku guru dan buku siswa. Namun karena terbatasnya materi pada kedua buku tersebut, guru mencari materi melalui sumber lainnya seperti buku teks dan sumber-sumber di internet. Ketiga, untuk menentukan metode pembelajaran, guru mengacu pada buku guru atau silabus. Untuk menentukan jenis media dilakukan berdasarkan KD dan indikator yang dibelajarkan. Media yang digunakan sebagian besar diperoleh dengan cara membeli walaupun ada beberapa guru yang memproduksi media sendiri. Terakhir, yaitu pada komponen penilaian yang dibuat dengan mengacu pada buku guru. Ada juga guru yang mengembangkan instrumen penilaian sendiri sesuai dengan indikator pembelajaran.

Analisis terhadap hasil dapat dibedakan menjadi tiga yaitu, analisis terhadap RPP, LKS, dan buku siswa pada kurikulum 2013. Berikut dipaparkan hasil analisis terhadap ketiga jenis perangkat pembelajaran tersebut.

Analisis RPP dilakukan pada tiga SD yang ada di Kabupaten Buleleng yang menerapkan kurikulum 2013. RPP yang dianalisis dari kelas I hingga kelas VI dan setiap kelas diambil satu tema untuk dianalisis. Hasil penilaian RPP K13 disajikan pada Tabel 1 
Tabel 1 Hasil Penilaian RPP K13

\begin{tabular}{|c|c|c|c|}
\hline \multicolumn{2}{|c|}{ Description Matrix } & \multicolumn{2}{|c|}{ Judgment Matrix } \\
\hline $\begin{array}{l}\text { Intens } \\
\text { RPP }\end{array}$ & Observasi & Standar & Judgments \\
\hline $\begin{array}{l}\text { RPP yang dibuat } \\
\text { guru SD sesuai } \\
\text { dengan standar } \\
\text { proses Permendikbud } \\
\text { No } 22 \text { tahun } 2016\end{array}$ & $\begin{array}{l}\text { Aktualitas } \\
\text { ketercapaian RPP } \\
\text { yang dibuat guru } \\
\text { SD sebanyak } \\
79,29 \% \\
\text { kategori Baik. } \\
\text { Belum semua guru } \\
\text { SD merencanakan } \\
\text { pembelajaran sesuai } \\
\text { dengan kriteria yang } \\
\text { telah ditetapkan } \\
\text { dalam standar } \\
\text { proses } \\
\text { Permendikbud No } \\
22 \text { tahun } 2016 .\end{array}$ & $\begin{array}{l}\text { Komponen RPP berdasarkan } \\
\text { Standar Proses } \\
\text { Pembelajaran meliputi: } \\
\text { a. Identitas sekolah yaitu } \\
\text { nama satuan pendidikan; } \\
\text { b. Identitas mata pelajaran } \\
\text { atau tema/subtema; } \\
\text { c. Kelas/semester; } \\
\text { d. Materi pokok; } \\
\text { e. Alokasi waktu } \\
\text { f. Tujuan pembelajaran } \\
\text { g. Kompetensi dasar dan } \\
\text { indikator pencapaian } \\
\text { kompetensi; } \\
\text { h. Materi pembelajaran, } \\
\text { i. Metode pembelajaran, } \\
\text { j. Media pembelajaran, } \\
\text { k. Langkah-langkah } \\
\text { l. Pembelajaran } \\
\text { Penilaian hasil } \\
\text { pembelajaran. }\end{array}$ & $\begin{array}{l}\text { Beberapa RPP yang } \\
\text { dibuat guru SD } \\
\text { belum sesuai } \\
\text { dengan } \\
\text { Permendikbud No } \\
22 \text { tahun } \\
2016 \text { tentang } \\
\text { standar proses. }\end{array}$ \\
\hline
\end{tabular}

Berdasarkan hasil analisis ternyata RPP yang dibuat oleh para guru SD, pada umumnya berada pada kategori baik. Namun ada beberapa RPP yang tidak lengkap sesuai dengan permendikbud No. 22 tahun 2016. Adapun kekurangan yang masih ada. (1) pada bagian pendahuluan yaitu penyampaian apersepsi masih bersifat normatif, belum dirumuskan dalam bentuk kegiatan yang implementatif, (2) pada bagian penutup masih ada yang belum ada kegiatan tindak lanjut seperti remedial ataupun pengayaan, (3) pada komponen penilaian bentuk konkret kegiatan remedial dan pengayaan masih minim dan sebagian besar RPP belum menyamtumkannya, (4) pada bagian alat, media, dan sumber belajar jenisnya masih menoton, kurang bervariasi media maupun sumber belajar yang digunakan, (5) pada komponen penilaian, belum semua RPP mencantumkan kunci jawaban.

Hasil analisis LKS yang dibuat guru menunjukkan bahwa kualitas LKS guru masih kurang. LKS yang dianalisis dalam penelitian ini LKS dalam Kurikulum 2013 untuk siswa yang meliputi LKS untuk kelas I, II, III, IV, V, dan kelas VI. Pada Tabel 2 disajikan hasil analisis LKS dalam kurikulum 2013.

Tabel 2 Hasil Analisis LKS

\begin{tabular}{|c|c|c|c|}
\hline \multicolumn{2}{|c|}{ Description Matrix } & \multicolumn{2}{|l|}{ Judgment Matrix } \\
\hline Intens & Observasi & Standar & Judgments \\
\hline \multicolumn{4}{|l|}{ LKS } \\
\hline \multirow{12}{*}{$\begin{array}{l}\text { LKS yang dibuat } \\
\text { guru SD sesuai } \\
\text { dengan teori } \\
\text { pembuatan LKS dan } \\
\text { memuat pendidikan } \\
\text { karakter dalam rangka } \\
\text { mengembangkan sikap } \\
\text { spiritual dan sikap sosial } \\
\text { sesuai dengan Kurikulum } \\
\text { 2013. }\end{array}$} & Aktualitas & Komponen LKS berdasarkan & \multirow{12}{*}{$\begin{array}{l}\text { LKS yang } \\
\text { dibuat guru } \\
\text { sebagai besar } \\
\text { belum sesuai } \\
\text { dengan teori } \\
\text { pembuatan } \\
\text { LKS }\end{array}$} \\
\hline & ketercapaian LKS & Standar teori pembuatan LKS & \\
\hline & yang dibuat guru & meliputı: & \\
\hline & SD sebanyak 22,29\% & a. Memuat judul LKS & \\
\hline & Kategor1 sangat & b. Kesesuaian petunjuk belajar & \\
\hline & sebagai besar guru & $\begin{array}{l}\text { c. Rumusan kompetensi } \\
\text { operasional }\end{array}$ & \\
\hline & belum membuat RPP & d. Kesesuaian jenis atau tipe & \\
\hline & teori pengembangan & LKS dengan rumusan & \\
\hline & LKS & kompetensi & \\
\hline & & $\begin{array}{l}\text { e. Kecukupan uraian materi } \\
\text { pokok }\end{array}$ & \\
\hline & & $\begin{array}{l}\text { f. Kejelasan tugas atau } \\
\text { langkah-langkah kerja }\end{array}$ & \\
\hline & & g. Kesesuaian penilaian & \\
\hline
\end{tabular}


LKS yang dibuat oleh guru ternyata secara kualitatif masih sangat kurang. Sesuai dengan teori pembuatan LKS bahwa LKS mesti memuat: Judul, petunjuk belajar, kompetensi, materi, langkah-langkah kerja, dan penilaian. Berdasarkan hasil analisis ditemukan bahwa: (1) LKS yang dibuat guru sebagian besar tidak mencantumkan judul atau topik, (2) LKS yang dibuat guru juga belum mencantumkan petunjuk belajar, (3) belum mencantumkan garis besar materi sebagai bahan atau pengetahuan untuk menyelesaikan suatu pekerjaan, dan (4) belum mencantumkan metode dan instrumen penilaian. Namun secara umum guru sudah merumuskan kompetensi berupa tujuan pembelajaran dan mencantumkan langkah-langkah kerja.

Buku teks pelajaran di SD diterbitkan oleh Kemendikbud. Buku yang dianalisis dalam penelitian ini Buku Teks Kurikulum 2013 untuk siswa yang meliputi buku kelas I, II, III, IV, V, dan kelas VI. Analisis dilakukan dari aspek desain pesan pembelajaran dan tidak menganalisis kebenaran isi atau materi. Hasil analisis disajikan pada Tabel 3.

Tabel 3 Hasil Analisis Buku Teks Pelajaran 2013

\begin{tabular}{|c|c|c|c|}
\hline \multicolumn{2}{|c|}{ Description Matrix } & \multicolumn{2}{|c|}{ Judgment Matrix } \\
\hline 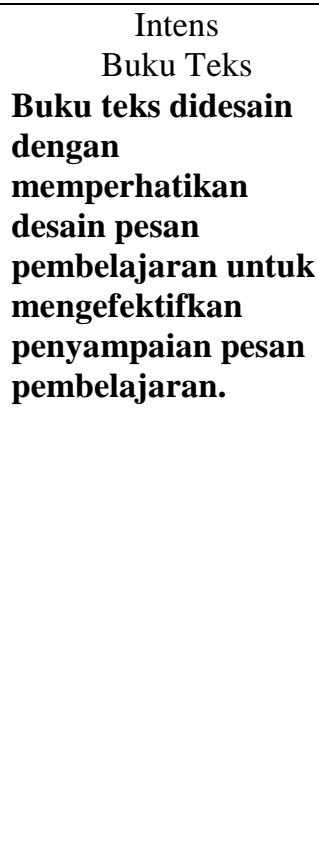 & $\begin{array}{l}\text { Aktualitas } \\
\text { ketercapaian Buku teks } \\
\text { pelajaran } \\
\text { kurikulum } 2013 \text { berada pada } \\
\text { kategori Sangat Baik }\end{array}$ & $\begin{array}{l}\text { Aspek penilaian Buku teks } \\
\text { berdasarkan aspek desain } \\
\text { pesan meliputi: } \\
\text { a. Ketepatan jenis, } \\
\text { ukuran, dan spasi } \\
\text { huruf } \\
\text { b. Kejelasan teks, } \\
\text { panjang teks, tata } \\
\text { ruang teks, variasi teks } \\
\text { c. Ketepatan tata ruang } \\
\text { teks } \\
\text { d. Kemenarikan sampul } \\
\text { e. Kemenarikan dan } \\
\text { kejelasan gambar } \\
\text { f. Ketepatan pemilihan } \\
\text { garna } \\
\text { g. Ketepatan penggunaan } \\
\text { contoh dan non contoh } \\
\text { h. Ketepatan layout }\end{array}$ & $\begin{array}{l}\text { Secara umum } \\
\text { kualitas buku teks } \\
\text { kurikulum } 2013 \\
\text { sudah sangat baik }\end{array}$ \\
\hline
\end{tabular}

Buku teks kurikulum 2013 sudah sangat baik, namun ada beberapa hal yang perlu diperbaiki dan ditambahkan dari aspek desain pesan pembelajaran. (1) petunjuk dalam mengerjakan tugas maupun latihan belum jelas sehingga sangat mungkin menyebabkan kebingungan pada siswa jika tanpa bimbingan dari guru, (2) buku teks masih kurang pemberian contoh dan non contoh untuk membelajarkan suatu konsep, (3) beberapa gambar tidak ada keterangan teks sehingga dapat membingungkan siswa tentang makna gambar tersebut, (4) ada beberapa spasi yang terlalu lingkar, dan (5) ada beberapa gambar dan teksnya saling berjauhan.

Berdasarkan hasil analisis bahwa persiapan yang dilakukan guru dalam membuat perangkat pembelajaran 2013 sudah termasuk sangat baik. Guru-guru telah mengikuti berbagai kegiatan baik itu sosialisasi, workshop, maupun diskusi melalui kelompok kerja guru (KKG). Kegiatan tersebut telah banyak memberikan pemahaman kepada guru tentang cara membuat RPP yang baik sesuai dengan Permendibud No. 22 Tahun 2016. Jadi, dari aspek persiapan para guru telah melakukan usaha-usaha maksimal untuk membuat perangkat pembelajaran khususnya berupa RPP.

Proses yang dilakukan guru telah berjalan dengan maksimal. Namun ada kendala yang dihadapi guru yaitu, terbatasnya materi pada buku guru dan buku siswa serta rumitnya membuat penilaian karena ada tiga aspek yang mesti dinilai yaitu sikap, pengetahuan, dan keterampilan. Kendala yang dihadapi guru diduga karena terjadinya masa perubahan dari kurikulum KTSP ke kurikulum 2013. Ada penambahan aspek pada perangkat pembelajaran kurikulum 2013 menyebabkan guru mengalami kesulitan. Namun dengan dilakukannya diskusi melalui tim kerja guru sehingga kesulitan yang dihadapi dapat diatasi.

Ada tiga hasil atau produk yang dianalisis dalam penelitian ini yaitu, RPP, LKS, dan buku siswa. RPP dan LKS dibuat oleh guru sedangkan buku siswa diterbitkan oleh kemendikbud. Berdasarkan hasil analisis bahwa kualitas RPP guru khususnya bagi sekolah yang menerapkan kurikulum 2013 di Kabupaten Buleleng berada pada kategori Baik. Ada beberapa faktor yang diduga diperolehnya kategori baik. Pertama, dikaji dari 
persiapan guru bahwa guru-guru telah mengikuti berbagai sosialisasi, workshop, maupun diskusi melalui kelompok kerja guru yang sangat besar memberikan pemahaman kepada guru dalam menyusun perangkat pembelajaran khususnya berupa RPP. Kegiatan tersebut dinilai efektif dan sangat membantu guru dalam penyusunan RPP. Kedua, proses yang dilakukan guru menyusun RPP sudah sistematis. Hal ini sesuai dengan teori desain pembelajaran dalam membuat RPP yaitu dilakukan secara sistematis. Proses pembuatan RPP dilakukan mulai dari menganalisis kompetensi, mengembangkan materi, menentukan metode dan strategi pembelajaran, menentukan media, membuat langkah-langkah pembelaja-ran, dan membuat penilaian. Ketiga, dengan adanya buku guru, para guru lebih mudah membuat langkah-langkah pembelajaran. Buku guru memberikan gambaran tentang standar pembelajaran yang dapat diterapkan guru. Namun ada juga guru yang mengembangkan langkah-langkah pembelajaran yang lebih inovatif sehingga RPP yang dibuat guru relevan dengan kondisi dan karakteristik siswa.

Berdasarkan hasil analisis bahwa LKS yang dibuat guru berada pada kategori sangat kurang. Ini mengindikasikan bahwa LKS yang dibuat guru belum sepenuhnya menggunakan teori pengembangan LKS. Dalam kenyataan di lapangan bahwa banyak penerbit yang menjual LKS di sekolah-sekolah dan LKS tersebut menyerupai bank soal. Dengan adanya LKS itu, membuat para guru kurang berinisiatif membuat LKS sendiri. Sejatinya LKS yang baik adalah LKS yang mampu mengembangkan daya nalar dan kreativitas siswa. Namun LKS yang dibuat oleh guru masih memiliki banyak kekurangan seperti, belum lengkapnya unsur-unsur LKS, lebih banyak mengukur kemampuan mengingat, dan belum sistematis. Berdasarkan teori pengembangan LKS, bahwa LKS setidaknya memuat: 1) memuat judul LKS, 2) kesesuaian petunjuk belajar, 3) rumusan kompetensi operasional, 4) Kesesuaian jenis atau tipe LKS dengan rumusan kompetensi, 5) kecukupan uraian materi pokok, 6) kejelasan tugas atau langkah-langkah kerja, 7) kesesuaian penilaian. Dari hasil analisis, LKS guru hanya memuat judul dan tugas atau langkah-langkah kerja. Sehingga LKS yang dibuat guru masih memiliki banyak kekurangan. Dengan demikian kedepannya perlu dilakukan suatu upaya berupa pelatihan agar guru-guru terampil membuat LKS yang baik dan benar.

Berdasarkan hasil penilaian dari aspek desain pesan bahwa buku siswa dalam kurikulum 2013 berada pada kategori sangat baik. Jika dibandingkan dengan buku pada kurikulum sebelumnya bahwa buku siswa K13 lebih menarik dan disajikan secara sistematis. Dikaji dari segi ketepatan jenis, ukuran, dan spasi huruf, buku kurikulum 2013 sudah menggunakan huruf yang tepat sehingga jelas dibaca oleh siswa. Dikaji dari kejelasan teks, panjang teks, tata ruang teks, variasi teks dan ketepatan tata ruang teks, buku K13 sudah sangat baik. Jumlah teks sangat memperhatikan karakteristik siswa sehingga tidak terlalu banyak teks maupun terlalu sedikit teks. Begitu juga dengan pengaturan tata letak teks sudah memperhatikan kenyamanan mata pembelajar, adanya ruang kosong, spasi horisontal maupun spasi vertikal. Dikaji dari kemenarikan sampul, buku K13 menggunakan gambar yang sesuai tema atau judul buku dan mencerminkan isi buku. Gambar yang digunakan juga menarik sehingga menumbuhkan minat baca siswa. Dikaji dari kemenarikan dan kejelasan gambar, buku K13 telah menggunakan gambar-gambar yang berwarna sehingga pesan yang disampaikan jelas, tidak menimbulkan miskonsepsi, memotivasi, dan gambar berwarna mampu menarik perhatian siswa. Warna yang digunakan pada buku K13 sangat tepat yaitu warna-warna yang kontras dimana warna tersebut adalah warna yang disukai anak-anak. Dikaji dari penyajian isi, sudah menggunakan contoh dan non contoh untuk memudahkan siswa belajar suatu konsep. Dari ketepatan layout sudah menggunakan tampilan yang nyaman di mata siswa dan dari segi ukuran sudah sangat tepat untuk anak SD.

\section{Simpulan dan Saran}

Berdasarkan hasil penelitian dan pembahasan, dapat disimpulkan sebagai berikut.

Pertama, persiapan yang dilakukan guru dalam pembuatan perangkat pembelajaran kurikulum 2013 sudah sangat efektif. Guru-guru telah mengikuti berbagai workshop tentang pembuatan perangkat pembelajaran 2013 khususnya berupa RPP.

Kedua, proses pembuatan perangkat pembelajaran khusus RPP telah dilakukan guru secara sistematis, mulai dari menganalisis kompetensi dan menjabarkannya, mengembang-kan materi, menentukan metode dan starategi pembelajaran, menentukan media pembelajaran, membuat langkah-langkah pembelajaran, dan membuat penilaian.

Ketiga, penilaian hasil menunjukkan bahwa RPP yang dibuat oleh guru SD dalam rangka penerapan kurikulum 2013 berada pada kategori baik, LKS berada pada kategori sangat kurang, dan buku teks kurikulum 2013 berada pada kategori sangat baik.

Saran kepada guru yang dapat disampaikan berdasarkan penelitian yang telah dilakukan adalah sebagai berikut: (1) guru dalam membuat RPP agar mengikuti ketentuan yang ada pada Permendikbud No. 22 tahun 2016, (2) pada komponen apersepsi agar dirumuskan secara implementatif sehingga pada saat pelaksana guru tidak kelabakan mencari apersepsi pembelajaran, (3) pada komponen penilaian perlu disajikan kegiatan remedial maupun pengayaan, dan (4) dalam membuat LKS perlu memperhatikan komponen-komponen LKS berdasarkan teori untuk memudahkan siswa mengerjakan LKS. 


\section{Daftar Pustaka}

Arifin, Zainal. 2010. Model-model Evaluasi Program. Artikel Online. Tersedia pada http://file.upi.edu. (diakses 9 Mei 2016).

Arikunto, Suharsimi. 2012. Dasar-dasar Evaluasi Pendidikan. Jakarta: PT. Bumi Aksara

Elmubarok, Z. 2009. Menumbuhkan Pendidikan Nilai: Mengumpulkan yang Terserak, Menyambung yang Terputus, dan Menyatukan yang Tercerai. Bandung: Alfabeta.

Fleming, Malcolm dan Levie, W. Howard. 1993. Instructional Message Design: Principles From The Behavioral Scienses. Second Edition. Englewood Cliffs, NJ: Educational Technology Publications, Inc.

Gagne, R. M., Briggs, L. J., \& Wager, W. W. 1992. Principles of Instructional Design (4 ${ }^{\text {th }}$ ed.). Forth Worth, TX: Harcourt Brace Jovanovich College Publishers.

Kaufman, R. \& Thomas S (1980). Evalution without Fear. New York Viewpoints.

Kemdiknas. 2010. Pengembangan Pendidikan Budaya dan Karakter Bangsa. Jakarta: Pusat Kurikulum Badan Penelitian dan Pengembangan Kemdiknas.

Koyan. 2012. Evaluasi Program Pendidikan. Singaraja: Universitas Pendidikan Ganesha.

Mustari, Mohamad. 2011. Nilai karakter: Refleksi untuk Pendidikan Karakter. Yogyakarta: LaksBangPrendssio.

Permendikbud nomor 22 tahun 2016 Tentang Standar Proses pada Pendidikan Dasar dan Pendidikan Menengah. Jakarta: Kemendikbud RI.

Prastowo, A. 2011. Panduan Kreatif Membuat Bahan Ajar Inovatif. Yogyakarta: Dipa Press.

Sadia, I W., Arnyana, I.B.P., Muderawan, I W. 2013. Model pendidikan karakter terintegrasi pembelajaran sains. Jurnal Ilmiah Pendidikan dan Pembelajaran. 3 (9).

Sanjaya, Wina, H. 2013. Perencanaan dan Desain Sistem Pembelajaran. Jakarta: Kencana.

Silberman, Mel. 2013. Pembelajaran Aktif: 101 Strategi untuk Mengajar Secara Aktif. (terjemahan). Jakarta: PT. Indeks.

Smith. P.L dan Ragan, T.J. 1999. Instructional Design. New York: Wiley.

Sugiyono. 2008. Metode Penelitiankunatitatif Kualitatif dan $R \& D$. Bandung: Alfabeta.

Suparman, M. A. 2012. Desain instruksional modern. Jakarta: Erlangga.

Tayibnapis, F. Y. 2000. Evaluasi Program. Jakarta: Rineka Cipta.

Wianaya, I Kadek, Suarjana, I Made, \&Mahadewi, LuhPutuPutrini. 2015. Analisis rencana pelaksanaan pembelajaran menurut kurikulum 2013 kelas IV SD No. 4 Banyuasri. E-journal PGSD Universitas Pendidikan Ganesha. 3 (1). 